\title{
Midwife Competency Standards and Midwife Authority in Emergency Delivery
}

(Services Standar Kompetensi Bidan dan Kewenangan Bidan dalam Pelayanan Kegawatdaruratan Persalinan)

${ }^{1}$ Noviyanti; ${ }^{2}$ Endang Wahyati; ${ }^{3}$ Tammy J. Siarif

email : inga.novi@gmail.com

\author{
1, 3 Midwifery Program, School of Health Sciences Jenderal Achmad Yani Cimahi, \\ West Java, Indonesia \\ ${ }^{2}$ Master of Health Law, Soegijapranata Catholic University Semarang
}

\begin{abstract}
Midwife as a professional has Competency standards of midwife consist of nine competencies which organize basic knowledge, additional knowledge, and skills of midwives in providing services. Midwife authorities are currently regulated under PMK No. 1464 in 2010 concerning License and Operation of Midwives Practice in which emergency authority during labour is limited by the conditions of the place. This study uses an approach method that is normative juridical, it is a way of examining law research conducted over reading materials or merely secondary data and using the method of deductive thinking as well as the criterion of coherence truth. Not every assessment in labour can be performed independently by midwives. Based on the competency standards of the midwife in Kepmenkes 369 in 2007 concerning the standard of the midwifery profession, competencies required in a midwife profession covers a very wide knowledge and skills, while the authorities of the profession can be said limited. In terms of their presence in a city close to secondary/ tertiary health care facilities, their role is very limited. Reviewing aspects of applicability of the law, it is not limited by space and time, so that there is a consistency of law, law certainty, therefore, relates to the regulation of competency standard that is associated with midwife authority becomes inconsistent.
\end{abstract}

Keyword: Midwife, Competency, Authority, and Emergency in Labor

\begin{abstract}
Abstrak: Bidan sebagai tenaga profesional memiliki Standar kompetensi bidan yang terdiri dari sembilan kompetensi yang mengatur pengetahuan dasar, pengetahuan tambahan, dan keterampilan bidan dalam memberikan pelayanan. Kewenangan bidan saat ini diatur dalam PMK No. 1464 Tahun 2010 tentang Perizinan dan Penyelenggaraan Praktek Bidan dimana kewenangan darurat selama persalinan dibatasi oleh kondisi tempat. Penelitian ini menggunakan metode pendekatan yang bersifat yuridis normatif, yaitu suatu cara pemeriksaan penelitian hukum yang dilakukan atas bahan bacaan atau data sekunder semata dan menggunakan metode berpikir deduktif serta kriteria kebenaran koherensi. Tidak setiap pengkajian dalam persalinan dapat dilakukan secara mandiri oleh bidan. Berdasarkan standar kompetensi bidan dalam Kepmenkes 369 tahun 2007 tentang standar profesi bidan, kompetensi yang dibutuhkan dalam profesi bidan meliputi pengetahuan dan keterampilan yang sangat luas, sedangkan kewenangan profesi dapat dikatakan terbatas. Dalam hal kehadiran mereka di kota yang dekat dengan fasilitas kesehatan sekunder/tersier, peran mereka sangat terbatas. Meninjau aspek keberlakuan undang-undang, tidak dibatasi oleh ruang dan waktu, sehingga ada konsistensi hukum, kepastian hukum, oleh karena itu terkait dengan pengaturan standar kompetensi yang dikaitkan dengan kewenangan bidan menjadi tidak konsisten.
\end{abstract}

Kata Kunci: Bidan, Kompetensi, Wewenang, dan Kegawatdaruratan Dalam Persalinan

\section{LATAR BELAKANG}

Keberadaan tenaga kesehatan merupakan salah satu asset dalam pembangunan bangsa, yang memiliki tugas mulia dalam upaya untuk mewujudkan masyarakat hidup sehat. Menurut 
SOEPRA Jurnal Hukum Kesehatan

TERAKREDITASI RISTEKDIKTI Peringkat 4

ISSN:2548-818X (media online) Vol. 7 (1) Juni 2021

Peraturan Pemerintah Nomor 36 Tahun 2014 Tentang Tenaga Kesehatan, bahwa tenaga kesehatan yang dimaksud salah satunya adalah bidan disamping tenaga medik, keperawatan dan penunjang kesehatan lainnya. Bidan dalam melaksanakan tugas haruslah telah memenuhi persyaratan, antara lain mengikuti pendidikan dan lulus serta diberikan lisensi oleh pemerintah untuk menjalankan praktik kebidanan.

Perkembangan dan kemajuan teknologi informasi, kesadaran hukum dan pemahaman masyarakat terhadap kesehatan ibu dan anak, berdampak pada tingginya tuntutan masyarakat akan pelayanan yang aman, bermutu dan dapat melindungi pasien, karena pelayanan kesehatan saat ini telah ditempatkan sebagai industri jasa kesehatan. Oleh karena itulah bidan selaku tenaga kesehatan harus selalu menekankan akan mutu pelayanan sesuai dengan wewenang dan standar kompetensinya serta ruang lingkup asuhan kebidanan yaitu mulai dari masa pra hamil, kehamilan, masa persalinan, masa nifas, masa menyusui dan masa antara dua kehamilan. Berdasarkan data yang dirilis, mencatat beberapa laporan tentang adanya dugaan pelanggaran (malpraktik) yang dilakukan oleh bidan terutama dalam memberikan pelayanan pada masa persalinan karena output pelayanan dianggap tidak aman, walaupun dugaan tersebut perlu pembuktian, apakah berkaitan dengan kurangnya kompetensi (under competency) dari profesi bidan atau diduga melampaui kewenangannya, yang seharusnya dilakukan oleh tenaga medis lainnya (dokter spesialis obgyn).

Untuk menjaga dan menjamin mutu pelayanan tersebut diperlukan suatu standar profesi yang meliputi standar kompetensi dan landasan hukum dalam bentuk peraturan perundang undangan yang mengatur tentang kewenangan bidan sebagai acuan dasar dalam melakukan segala tindakan dan asuhan kebidanan yang diberikan dalam seluruh aspek pengabdian profesinya kepada individu, keluarga dan masyarakat, baik dari aspek input, proses dan output.

Saat ini kaidah tentang standar kompetensi bidan telah diatur dalam Kepmenkes Nomor 369/Menkes/SK/III/2007 Tentang Standar Profesi Bidan, yang mengatur tentang persyaratan dan jenis kompetensi yang harus dimiliki bidan dalam memberikan pelayanan kebidanan yang salah satunya adalah kompetensi ke 4 (empat) tentang asuhan selama persalinan dan kelahiran. Pada kompetensi tersebut dijelaskan bahwa bidan harus mempunyai kompetensi berupa pengetahuan dasar tentang indikasi tindakan kegawat daruratan dan pengetahuan tambahan tentang penatalaksanaan persalinan dengan malpresentasi. Sedangkan kompetensi bidan dalam penanganan kegawat daruratan pada masa persalinan nampak berbeda dengan pengaturan yang terdapat dalam UU No 4 Tahun 2019 tentang Kebidanan, yang mana dinyatakan bahwa seorang bidan dapat melakukan penanganan kegawat daruratan, dilanjutkan dengan rujukan. Hal ini tentunya menimbulkan perbedaan penafsiran tentang kewenangan bidan dalam menangani kasus kegawatdaruratan terutama didaerah terpencil yang jauh dari pusat rujukan.

Tumbuhnya kesadaran terhadap pengakuan dan penghormatan akan hak-hak asasi manusia khususnya di bidang kesehatan dan semakin tingginya pengetahuan pasien atas berbagai masalah kesehatan, serta adanya perkembangan pola pikir masyarakat akan perlindungan hukum berdampak pada relasi/ hubungan antara bidan dengan pasien tidak hanya sebagai hubungan terapeutik saja tapi telah berkembang hingga menyentuh pada persoalan pidana dan perdata, terutama bila muncul kecurigaan dalam diri pasien bahwa ada dugaan tindakan malpraktik yang dilakukan bidan. Hal ini mendorong para profesi mendapatkan landasan hukum untuk mempertegas akan fungsi, tugas dan wewenang bidan, salah satunya dalam penanganan kegawatdaruratan dalam pelayanan persalinan. 
SOEPRA Jurnal Hukum Kesehatan

TERAKREDITASI RISTEKDIKTI Peringkat 4

ISSN:2548-818X (media online) Vol. 7 (1) Juni 2021

Penelitian ini akan menganalisis tentang hubungan antara kaidah standar kompetensi bidan dengan kaidah kewenangan pelayanan dalam melakukan penanganan kegawatdaruratan pada masa persalinan, sehingga dipilih judul "standar kompetensi bidan dan kewenangan bidan dalam pelayanan kegawat-daruratan persalinan".

\section{PERUMUSAN MASALAH}

Untuk mendapatkan gambaran yang sistematis maka akan diidentifikasikan masalah penelitian yaitu :

1. Bagaimanakah Kaidah standar kompetensi bidan?

2. Bagaimanakah Kaidah kewenangan bidan dalam pelayanan kegawatdaruratan persalinan?

3. Apakah terdapat hubungan sebab akibat antara kaidah standar kompetensi bidan dengan kaidah kewenangan bidan dalam pelayanan kegawatdaruratan persalinan?

\section{METODE PENELITIAN}

Metode pendekatan yang digunakan dalam penelitian ini, yaitu yuridis normative, yaitu suatu cara meneliti dalam penelitian hukum yang dilakukan terhadap bahan pustaka atau data sekunder belaka dan dengan menggunakan metode berpikir deduktif serta kriterium kebenaran koheren. Selanjutnya yang dimaksud dengan metode berpikir deduktif adalah cara berpikir dalam penarikan kesimpulan yang ditarik dari sesuatu yang sifatnya umum yang sudah dibuktikan bahwa dia benar dan kesimpulan itu ditujukan untuk sesuatu yang sifatnya khusus. ${ }^{1}$ Sedangkan yang dimaksud dengan kebenaran koheren (the coherence theory of truth), adalah suatu pengetahuan, teori, pernyataan, proposisi, atau hipotesis dianggap benar kalau sejalan dengan pengetahuan, teori, pernyataan, proposisi, atau hipotesis lainnya, yaitu kalau proposisi itu meneguhkan dan konsisten dengan proposisi sebelumnya yang dianggap benar. ${ }^{2}$

Pada penelitian ini menggunakan data sekunder berupa bahan-bahan kepustakaan yang meliputi literatur yang berkaitan dengan Hukum dan perundang-undangan, jurnal hukum kesehatan, dan sumber lain yang terkait dengan profesi bidan, standar kompetensi bidan dan kewenangnnya dalam memberikan pelayanan kebidanan terutama pelayanan dalam tindakan kegawatdaruratan persalinan. Penelitian ini dilakukan dengan mendiskripsikan tentang kompetensi kegawatdaruratan dan kewenangan kegawatdaruratan bidan pada masa persalinan serta hubungan keduanya dalam pelayanan kegawatdaruratan persalinan.

\section{PEMBAHASAN}

\section{Standar kompetensi bidan}

Menurut Surat Keputusan Menteri Pendidikan Nasional nomor 045/U/2002 tentang Kurikulum Inti Perguruan Tinggi dijelaskan bahwa "Kompetensi adalah seperangkat tindakan cerdas, penuh tanggungjawab yang dimiliki seseorang sebagai syarat untuk dianggap mampu oleh masyarakat dalam melaksanakan tugas-tugas di bidang pekerjaan tertentu".

\footnotetext{
1 Sedarmayanti \& Syarifudin Hidayat, 2002, Metodologi Penelitian, Bandung: Mandar Maju, hlm. 23.

2 A. Sonny Keraf \& Mikhael Dua, 2001, Ilmu Pengetahuan (Sebuah Tinjauan Filosofis), Yogyakarta : Kanisius, hlm. 68.
} 
Adapun yang dimaksud Kompetensi bidan adalah meliputi pengetahuan, keterampilan dan perilaku yang harus dimiliki oleh seorang bidan dalam melaksanakan praktik kebidanan secara aman dan bertanggung jawab pada berbagai tatanan pelayanan kesehatan. Kompetensi tersebut dikelompokkan dalam 2 (dua) kategori yaitu kompetensi inti/dasar merupakan kompetensi minimal yang mutlak dimiliki oleh bidan, kompetensi tambahan/lanjutan merupakan pengembangan dari pengetahuan dan keterampilan dasar untuk mendukung tugas bidan dalam memenuhi tuntutan atau kebutuhan masyarakat yang sangat dinamis serta perkembangan IPTEK.

Bidan sebagai profesi dalam melaksanakan tindakan profesionalnya wajib memenuhi standar kompetensi yang telah ditetapkan oleh pemerintah sebagaimana diatur dalam peraturan perundang-undangan.

\section{a) Dasar Hukum Standar Kompetensi Bidan}

1) Undang Undang Nomor 36 Tahun 2009 tentang Kesehatan.

Menurut ketentuan Pasal 21 dan Pasal 22 dinyatakan :

Pasal 21

(1) "Pemerintah mengatur perencanaan, pengadaan, pendayagunaan, pembinaan, \& pengawasan mutu tenaga kesehatan dalam rangka penyelenggaraan pelayanan kesehatan.

(2) Ketentuan mengenaiperencanaan, pengadaan, pendayagunaan, pembinaan, dan pengawasan mutu tenaga kesehatan sebagaimana dimaksud pd ayat (1) diatur dalam Peraturan Pemerintah.

(3) Ketentuan mengenai tenaga kesehatan diatur dengan Undang Undang."

Pasal 22

(1) "Tenaga kesehatan harus memiliki kualifikasi minimum.

(2) Ketentuan mengenai kualifikasi minimum sebagaimana dimaksud pada ayat (1) diatur dengan Peraturan Menteri."

Dalam Undang Undang No 36 tahun 2009 tentang Kesehatan memberikan landasan hukum bagi pemerintah untuk mengatur sumber daya kesehatan. Pengaturan tersebut memberi mandat kepada pemerintah sebagai pembuat regulasi/kebijakan untuk mengatur, merencanakan termasuk pengadaan tenaga kesehatan, pendayagunaan hingga pengawasan mutu tenaga kesehatan agar dalam menjalankan tugasnya dapat meningkatkan derajat kesehatan yang setinggitingginya. Dalam kerangka tercapainya maksud diatas dalam undang-undang juga mensyaratkan untuk setiap tenaga kesehatan dalam melaksanakan tugasnya harus memiliki dan memenuhi kualifikasi minimum (stndar kompetensi) agar dapat menjamin terselenggaranya pelayanan yang aman,efektif dan efisien serta dapat memenuhi harapan masyarakat.

Berdasarkan ketentuan tersebut, bidan sebagai tenaga kesehatan harus memiliki kompetensi yang mencakup pengetahuan dan keterampilan sebagai syarat dalam memberikan asuhan kebidanan yang diatur dalam standar pendidikan, standar pelayanan dan standar kompetensi bidan.

Undang Undang Kesehatan ini merupakan payung hukum untuk untuk pembuatan peraturan-peraturan tehnis selanjutnya, hal ini Nampak dalam Undang Undang memandatkan untuk pengaturan selanjutnya baik oleh Presiden melalui Peraturan Pemerintah (PP), Perpres/ Keppres maupun Peraturan Menteri. 
2) Peraturan Pemerintah Nomor 36 Tahun 2014 tentang Tenaga Kesehatan. Menurut ketentuan Pasal 3 dinyatakan :

"Tenaga kesehatan wajib memiliki pengetahuan dan keterampilan di bidang kesehatan yang dinyatakan dengan ijazah dari lembaga pendidikan."

Menurut Penjelasan Pasal 3 ditegaskan :

"Persyaratan pengetahuan dan keterampilan di bidang kesehatan bagi tenaga kesehatan harus sesuai dengan jenis dan jenjang pendidikannya."

Kemudian Pasal 8

(1) “Pendidikan di bidang kesehatan dilaksanakan di lembaga pendidikan yang diselenggarakan oleh Pemerintah atau masyarakat.

(2) Penyelenggaraan pendidikan di bidang kesehatan sebagaimana dimaksud dalam ayat (1) dilaksanakan" berdasarkan ijin sesuai dengan ketentuan peraturan perundang-undangan yang berlaku."

Peraturan Pemerintah Nomor 36 tahun 2014 menegaskan syarat formal yang berbentuk tertulis agar kompetensi yang dimiliki tenaga kesehatan dapat diakui dan dianggap legal yang dibuktikan dengan ijazah, artinya seorang bidan memiliki kualifikasi kompetensi yang berwujud penguasaan pengetahuan dan ketrampilan yang diperoleh melalui proses pendidikan disahkan oleh lembaga yang diizinkan menyelenggarakan pendidikan program tersebut. Selanjutnya untuk menguji kemampuan klinisnya dilakukan uji kompetensi, bila hal tersebut dinyatakan lulus maka akan diberikan sertifikasi kompetensi

Mengacu pada Peraturan Menteri Kesehatan Nomor 46 Tahun 2013 tentang Sertifikasi Tenaga Kesehatan, bahwa setelah peserta didik tenaga kesehatan (diluar dokter dan kefarmasian) dinyatakan lulus maka harus ikut uji kompetensi yang diselenggarakan oleh lembaga pendidikan dan organisasi profesi (ke depan MTKI/MTKP) untuk mendapatkan sertifikasi. Hal ini dimaksudkan untuk mendapatkan legalisasi dari kompetensi yang telah dimiliki oleh tenaga kesehatan.

\section{b) Bentuk Pengaturan Standar Kompetensi Bidan}

Keputusan Menteri Kesehatan Nomor 369 tahun 2007 tentang Standar Profesi bidan. Kedudukan Keputusan menteri tersebut merupakan peraturan pelaksanaan / peraturan tehnis (eununsitive) yang berisi tentang pedoman-pedoman yang wajib dilaksanakan oleh tenaga kesehatan khususnya untuk Profesi Bidan dalam memberikan asuhan kebidanan kepada masyarakat.

Di dalam Kepmenkes tersebut mengatur tentang kompetensi bidan terdiri dari Sembilan kompetensi yang mengandung unsur pengetahuan dasar, pengetahuan dan keterampilan tambahan serta prilaku profesional bidan. Sembilan kompetensi bidan tersebut adalah:

1) "Pengetahuan dan keterampilan dari ilmu-ilmu sosial, kesehatan masyarakat dan etik yang membentuk dasar dari asuhan yang bermutu tinggi sesuai dengan budaya, untuk wanita, bayi baru lahir dan keluarganya.

2) Bidan memberikan asuhan yang bermutu tinggi, pendidikan kesehatan yang tanggap terhadap budaya dan pelayanan menyeluruh dimasyarakat dalam rangka untuk meningkatkan kehidupan keluarga yang sehat, perencanaan kehamilan dan kesiapan menjadi orang tua. 
3) Bidan memberi asuhan antenatal bermutu tinggi untuk mengoptimalkan kesehatan selama kehamilan yang meliputi: deteksi dini, pengobatan atau rujukan dari komplikasi tertentu.

4) Bidan memberikan asuhan yang bermutu tinggi, tanggap terhadap kebudayaan setempat selama persalinan, memimpin selama persalinan yang bersih dan aman, menangani situasi kegawatdaruratan tertentu untuk mengoptimalkan kesehatan wanita dan bayinya yang baru lahir.

5) Bidan memberikan asuhan pada ibu nifas dan menyusui yang bermutu tinggi dan tanggap terhadap budaya setempat.

6) Bidan memberikan asuhan yang bermutu tinggi, komperhensif pada bayi baru lahir sehat sampai dengan 1 bulan.

7) Bidan memberikan asuhan yang bermutu tinggi, komperhensif pada bayi dan balita sehat ( 1 bulan -5 tahun).

8) Bidan memberikan asuhan yang bermutu tinggi dan komperhensif pada keluarga, kelompok dan masyarakat sesuai dengan budaya setempat.

9) Melaksanakan asuhan kebidanan pada wanita/ibu dengan gangguan sistem reproduksi".

Berdasarkan kompetensi tesebut, dijabarkan bahwa seorang bidan mempunyai kompetensi dalam memberikan asuhan persalinan yang bersih dan aman, cepat tanggap terhadap lingkungan dan mampu menangani situasi kegawatdaruratan tertentu untuk mengoptimalkan kesehatan wanita dan bayi yang baru dilahirkannya. Kompetensi persalinan mencakup antara lain:

1) "Pengetahuan dasar : a. diberikan pengetahuan tentang indikasi tindakan kedaruratan kebidanan seperti distosia bahu, asfiksia neonatal, retensio plasenta, perdarahan karena atonia uteri dan mengatasi rejatan, b. Indikasi tindakan operatif pada persalinan misalnya gawat janin, CPD, c. Indikator komplikasi persalian : perdarahan, partus macet, kelaianan presentasi, eklampsia kelelahan ibu, gawat janin, infeksi, ketuban pecah dini tanpa infeksi, distosia karena inersia uteri primer, posterm dan preterm serta tali pusat menumbung.

2) Pengetahuan tambahan : Penatalaksanaan Persalinan dengan malpresentasi.

3) Keterampilan dasar : a. Mengidentifikasi secara dini kemungkinan pola persalinan abnormal dan kegawatdaruratan dengan intervensi yang sesuai dan atau melakukan rujukan dengan tepat waktu, b. Menolong kelahiran bayi dengan lilitan tali pusat, c. Melakukan episiotomy dan penjahitan, jika diperlukan, d. Memberikan suntikan intramuskuler meliputi uterotonika, antibiotika dan sedative, e. Menjahit robekan vagina dan perineum tingkat II, f. Memberikan pertolongan persalinan abnormal : letak sungsang, partus macet kepala didasar panggul, ketuban pecah dini tanpa infeksi, post term dan preterm, g. Melakukan pengeluaran plasenta secara manual, h. Mengelola perdarahan post partum

4) Keterampilan tambahan : a. Menolong kelahiran presentasi muka dengan penempatan dan gerakan tangan yang tepat, b. Melakukan ekstraksi forcep rendah dan vakum jika diperlukan sesuai kewenangan, c. Mengidentifikasi dan mengelola malpresentasi, distosia bahu, gawat janin dan kematian janin dalam kandungan (IUFD) dengan tepat, d. Mengidentifikasi dan mengelola tali pusat menumbung, e. Mengidentifikasi dan menjahit robekan serviks, f. Membuat resep dan atau memberikan obat-obatan untuk mengurangi nyeri jika diperlukan sesuai 
kewenangan, g. Memberikan oksitosin dengan tepat untuk induksi dan akselerasi persalinan dan penanganan perdarahan post partum."

Terhadap 9 (Sembilan) jenis kompetensi bidan diatas merupakan kompetensi normal untuk melakukan asuhan kebidanan dalam kasus persalinan normal. Namun demikian pembuat kebijakan menyadari bahwa dalam proses tehnis sangat dimungkinan terjadi hal-hal yang bersifat kedaruratan artinya diluar dugaan, sehingga diperlukan kompetensi tambahan yang harus dikuasai oleh profesi bidan sebagai upaya tindakan cepat dalam rangka menyelamatkan ibu dan bayi yang dilahirkan. kondisi yang tidak normal dalam persalinan maka perlu tindakan kegawatdaruratan kebidanan seperti : distosia bahu, asfiksia neonatal, retensio plasenta, perdarahan karena atonia uteri dan mengatasi rejatan. Selain itu terdapat juga pengetahuan dasar bidan dalam indikasi tindakan operatif dan indikator komplikasi persalinan yang mencakup perdarahan, partus macet, kelainan presentasi, eklamsia kelelahan ibu, gawat janin, infeksi, ketuban pecah dini tanpa infeksi, distosia karena inersia uteri primer, post term dan preterm serta tali pusat menumbung.

\section{Ketentuan kewenangan bidan}

Pengertian Kewenangan menurut P. Nicolai adalah kemampuan untuk melakukan tindakan hukum tertentu yaitu tindakan-tindakan yang dimaksudkan untuk menimbulkan akibat hukum, dan mencakup mengenai timbul dan lenyapnya akibat hukum. ${ }^{3}$

Secara pengertian bebas kewenangan adalah hak seorang individu untuk melakukan sesuatu tindakan dengan batas-batas tertentu dan diakui oleh individu lain dalam suatu kelompok tertentu.

Kewenangan merupakan suatu bentuk kemampuan hak dan kekuasaan seorang bidan untuk melakukan asuhan/pelayanan kebidanan sebagaimana ditentukan dalam hak dan kewajiban bidan. Profesi Bidan dalam memberikan asuhan kebidan harus sesuai dengan kewenangannya setelah diberikan lisensi oleh pemerintah dalam bantuk Surat tanda registrasi (STR).

\section{a) Dasar Hukum Kewenangan Bidan.}

1) Undang Undang Nomor 36 Tahun 2009 tentang Kesehatan. Menurut ketentuan Pasal 23 dinyatakan :

“(1) Tenaga kesehatan berwenang untuk menyelenggarakan pelayanan kesehatan.

(2) Kewenangan untuk menyelenggarakan pelayanan kesehatan sebagaimana dimaksud pada ayat (1) dilakukan sesuai dengan bidang keahlian yang dimiliki.

(3) Dalam menyelenggarakan pelayanan kesehatan, tenaga kesehatan wajib memiliki izin dari pemerintah."

Ketentuan tersebut berkedudukan sebagai payung hukum, bahwa setiap tenaga kesehatan termasuk profesi bidan memiliki kewenangan untuk menjalankan tugas profesinya sepanjang dilakukan sesuai dengan keahliannya (ayat 2). Hal itu tentu diperlukan validasi atas keahlian yang dimiliki yaitu melalui uji kompetensi dan sertifikasi oleh lembaga organisasi profesi yang berwenang untuk itu. Dengan demikian apabila seorang bidan memiliki bukti sertifikasi dan lisensi maka akan

\footnotetext{
3 Ridwan HR. 2007. Hukum Administrasi Negara. Yogyakarta. PT Raja Grafindo Persada hal. 101-102
} 
memiliki adanya kewenangan dari seorang profesi bidan untuk melakukan praktik kebidanan baik secara mandiri maupun di institusi pelayanan kesehatan.

2) Undang Undang nomor 29 Tahun 2004 tentang Praktik Kedokteran dan Peraturan Menteri Kesehatan Nomor 2052 Tahun 2011 tentang Izin Praktik dan Penyelenggaran Praktik Kedokteran.

Didalam peraturan diatur mengatur tentang pelimpahan kewenangan dari profesi dokter kepada tenaga kesehatan lainnya termasuk profesi bidan untuk melakukan tindakan yang seharusnya menjadi kewenangan dokter.

Menurut ketentuan pasal Pasal 23 Permenkes 2052 Tahun 2011 dinyatakan :

“(1) Dokter atau dokter gigi dapat memberikan pelimpahan suatu tindakan kedokteran atau kedokteran gigi kepadaperawat,bidan atau tenaga kesehatan tertentu lainnya secara tertulis dalam melaksanakan tindakan kedokteran atau kedokteran gigi.

(2) Tindakan kedokteran atau kedokteran gigi sebagaimana dimaksud pada ayat (1) hanya dapat dilakukan dalam keadaan di mana terdapat kebutuhan pelayanan yang melebihi ketersediaan dokter atau dokter gigi di fasilitas pelayanan tersebut.

(3) Pelimpahan tindakan sebagaimana dimaksud pada ayat (1) dilakukan dengan ketentuan:

a. tindakan yang dilimpahkan termasuk dalam kemampuan dan keterampilan yang telah dimiliki oleh penerima pelimpahan;

b. pelaksanaan tindakan yang dilimpahkan tetap di bawah pengawasan pemberi pelimpahan;

c. pemberi pelimpahan tetap bertanggung jawab atas tindakan yang dilimpahkan sepanjang pelaksanaan tindakan sesuai dengan pelimpahan yang diberikan;

d. tindakan yang dilimpahkan tidak termasuk mengambil keputusan klinis sebagai dasar pelaksanaan tindakan; dan

e. tindakan yang dilimpahkan tidak bersifat terus menerus."

Pelimpahan kewenangan melakukan tindakan kedokteran ini dapat dilakukan dengan syarat karena kekurangan tenaga dokter, dilimpahkan kepada tenaga kesehatan yang memiliki kompetensi, dilakukan terbatas dengan kewenangan apa yang dilimpahkan dan tidak boleh dilakukan terus menerus artinya untuk sementara.

Pelimpahan tindakan yang diberikan kepada bidan dilakukan dengan ketentuan:

a. Tindakan yang dilimpahkan termasuk dalam kemampuan dan keterampilan yang telah dimiliki oleh penerima pelimpahan;

b. Pelaksanaan tindakan yang dilimpahkan tetap di bawah pengawasan pemberi pelimpahan;

c. Pemberi pelimpahan tetap bertanggung jawab atas tindakan yang dilimpahkan sepanjang pelaksanaan tindakan sesuai dengan pelimpahan yang diberikan;

d. Tindakan yang dilimpahkan tidak termasuk mengambil keputusan klinis sebagai dasar pelaksanaan tindakan; dan

e. Tindakan yang dilimpahkan tidak bersifat terus menerus." 
Ketentuan ini mengatur tentang pelimpahan kewenangan oleh tenaga medis dalam hal ini dokter kepada tenaga kesehatan lainnya. Hal ini dapat terjadi pelimpahan untuk melakukan tindakan pelayanan diberikan kepada profesi bidan. Hal ini menunjukkan bahawa secara legal formal apa yang dilimpahkan adalah tindakan yang bukan menjadi kewenangannya, hanya karena situasi tertentu wewenang tersebut diberikan, hal ini menunjukkan peran dependent dari profesi bidan. Tindakan pelimpahan tersebut tidak dapat diberikan begitu saja melainkan ada batas-batasnya yang harus diikuti sebagaimana diatur dalam ketentuan diatas.

\section{b) Bentuk pengaturan dan Ruang Lingkup Kewenangan Bidan.}

Peraturan Menteri Kesehatan nomor 1464 Tahun 2010 tentang izin dan penyelenggaraan praktik bidan pasal 9 didalamnya mengatur mengenai perincian kewenangan bidan dalam memberikan asuhan kebidanan yang terdiri dari 3 hal yaitu : (a). pelayanan kesehatan ibu, (b). kesehatan anak dan (c) pelayanan kesehatan reproduksi perempuan dan Keluarga Berancana. Penjabaran atas area kewenangan dapat digambarkan sebagaimana ditentukan pada pasal 10 sebagai berikut : a). Pelayanan kesehatan ibu sebagaimana dimaksud dalam pasal 9 huruf a diberikan pada masa pra hamil, kehamilan, masa persalinan, masa nifas, masa menyusui dan masa antara dua kehamilan. b). Pelayanan kesehatan ibu sebagaimana dimaksud pada ayat (1) meliputi : Pelayanan konseling pada masa pra hamil, Pelayanan antenatal pada kehamilan normal, Pelayanan persalinan normal, Pelayanan ibu nifas normal, Pelayanan ibu menyusui, Pelayanan konseling pada masa antara dua kehamilan. C) Bidan dalam memberikan pelayanan sebagaimana dimaksud pada ayat 2 berwenang untuk : 1). Episiotomi, 2) Penjahitan luka jalan lahir tingkat I dan II, 3) Penanganan kegawat-daruratan, dlanjutkan dengan perujukan, 4) Pemberian tablet Fe pada ibu hamil, 5) Pemberian Vit A dosis tinggi pada ibu nifas, 6) Bimbingan inisiasi menyusui dini dan promosi ASI ekslusif, 7) Pemberian uterotonika pada manajemen aktif kala tiga dan postpartum, 8) Penyuluhan dan konseling, 9) Bimbingan pada kelompok ibu hamil, 10) Pemberian surat keterangan kematian, 11) Pemberian surat keterangan cuti bersalin.

Ketentuan tersebut diatas menunjukkan area dan batas-batasnya dimana seorang profesi bidan dapat menjalankan profesinya. Didalam kewenangan itu dalam ayat (3) butir $\mathrm{c}$ terdapat kewenangan lain yang berkaitan dengan hal-hal yang berkaitan dengan wewenang bidan dalam menangani kasus kegawatdaruratan mencakup :

a) Memberikan pelayanan kesehatan ibu pada masa persalinan.

Ketentuan tersebut memberikan perluasan area pelayanan kepada ibu semasa persalinan. Karena semasa persalinan ada kebutuhan-kebutuhan pelayanan yang harus diberikan dalam rangka menjaga kesehatan ibu yang sedang dan atau setelah persalinan termasuk merawat bayi.

b) Bidan dalam memberikan pelayanan berwenang untuk penanganan kegawatdaruratan, dilanjutkan dengan perujukan.

Ketentuan ini memberikan kewenangan kepada profesi bidan untuk memberikan tindakan dalam situasi tertentu sebelum ditangani oleh tenaga kesehatan yang mempunyai kewenangan untuk itu seperti dokter obgyn. Hal tersebut diberikan tujuannya untuk menolong sebelum dilakukan penanganan yang lebih intensif. Melalui tindakan diagnose awal tentang gejala dan kondisi kesehatan yang terdeteksi lebih awal maka akan member kontribusi penting untuk tindakan selanjutnya. 
c) Bagi bidan yang menjalankan praktik didaerah yang tidak memiliki dokter, dapat melakukan pelayanan kesehatan diluar kewenangan yang meliputi di daerah kecamatan, atau kelurahan/desa yang ditetapkan oleh kepala dinas kesehatan kabupaten/kota.

d) Ada kewenangan situasional yang diberikan kepada profesi kebidanan pada tempat-tempat tertentu yang tidak/ belum ada dokter. Di tempat ini profesi bidan boleh melakukan tindakan diluar kewenangannya untuk melakukan tindakan pelayanan kesehatan diluar kewenangan sebagaimana diatur dalam pasal 9.

e) Apabila tidak terdapat tenaga bidan minimal D III, maka pemerintah dan pemerintah daerah dapat menempatkan bidan yang telah megikuti pelatihan.

Ketentuan ini bertujuan untuk memenuhi kekurangan profesi bidan, maka ada bidan pelaksana yang belum memiliki pendidikan D III, dapat melakukan praktik bidan profesi setelah diberikan pelatihan oleh dinas kesehatan setempat.

3. Analisis hubungan ketentuan standar kompetensi bidan dalam kegawatdaruratan persalinan dan kewenangan bidan dalam pelayanan kegawat daruratan persalinan

Bidan sebagai tenaga profesional memiliki landasan hukum yang mengatur dan mengikat dalam pemberian pelayanan harus sesuai dengan keahliannya (kompetensi). Rincian kompetensi profesi bidan terdiri dari 9 (sembilan) Standar Kompetensi Bidan mencakup pemberian asuhan kebidanan normal maupun melakukan tindakan dalam kondisi kedaruratan persalinan. Kompetensi dimaksud mencakup penguasaan pengetahuan (knowledge), ketrampilan (skill) yang dilengkapi dengan sikap tertentu (morally) yang diatur dalam Kode aetik Bidan Indonesia. Kepemilikan dan penguasaan kompetensi perlu dibuktikan dengan ijazah dan sertifikasi kompetensi yang diperoleh dari uji kompetensi sebagai syarat untuk mendapatkan izin (lisensi) untuk melakukan tindakan asuhan kebidanan yang diberikan oleh institusi pemerintah dalam hal ini Dinas Kesehatan setempat.

Untuk dapat menjalankan praktiknya, profesi bidan harus memiliki kewenangan untuk memberikan pelayanan yang melekat dengan izin (lisensi) dari Dinas Kesehatan setempat. Ketentuan tentang kewenangan diatur dalam Permenkes 1464 Tahun 2010 tentang Izin dan Penyelenggaran Praktik Bidan pada pasal 9 dan pasal 10.

Rincian kewenangan bidan dalam memberikan asuhan dan pelayanan kebidanan meliputi selain asuhan yang fisiologis atau normal, juga diberikan kewenangan untuk menangani asuhan kebidanan dalam kondisi kedaruratan persalinan. Pengaturan tentang kewenangan profesi bidan merupakan bentuk legitimasi terhadap pelaksanaan asuhan kebidanan yang dilakukan oleh profesi bidan yang memenuhi persyaratan baik penguasaan kompetensi (syarat materiil) maupun bukti legal formalnya, sehingga profesi bidan mendap[atkan kepastian hokum dalam menyelenggarakan asuhan kebidanan.

Dengan demikian dapat dibuat hipotesa sementara bahwa penguasaan kompetensi profesi bidan hanya dapat diimplementasikan dalam asuhan kebidanan ketika memiliki kewenangan yang dalam hal ini lisensi dari institusi Dinas kesehatan setempat, demikian juga lisensi penyelenggaraan asuhan akan diberikan bila profesi memiliki kompetensi yang dibuktikan dengan kepemilikan ijazah dan sertifikasi kompetensi. Artinya kedua hal ini memiliki hubungan saling berkaitan dan saling mempengaruhi. 


\section{KESIMPULAN}

\section{a) Standar Kompetensi Bidan}

Kepmenkes Nomor 369 Tahun 2007 Tentang Standar Profesi Bidan mengatur tentang Sembilan kompetensi yang mengandung unsur pengetahuan dasar, pengetahuan dan keterampilan tambahan serta prilaku profesional bidan. Jenis kompetensi bidan merupakan kompetensi normal untuk melakukan asuhan kebidanan dalam kasus persalinan normal. Namun demikian pembuat kebijakan menyadari bahwa dalam proses tehnis sangat dimungkinan terjadi hal-hal yang bersifat kedaruratan artinya diluar dugaan, sehingga diperlukan kompetensi tambahan yang harus dikuasai oleh profesi bidan sebagai upaya tindakan cepat dalam rangka menyelamatkan ibu dan bayi yang dilahirkan.

\section{b) Kewenangan Bidan dalam Pelayanan Kegawatdaruratan Persalinan}

Peraturan Menteri Kesehatan nomor 1464 Tahun 2010 tentang izin dan penyelenggaraan praktik bidan pasal 9 didalamnya mengatur mengenai perincian kewenangan bidan dalam memberikan asuhan kebidanan yang terdiri dari 3 hal yaitu : (a). pelayanan kesehatan ibu, (b). kesehatan anak dan (c) pelayanan kesehatan reproduksi perempuan dan Keluarga Berancana. Didalam kewenangan tersebut dalam ayat (3) butir c terdapat kewenangan lain yang berkaitan dengan hal-hal yang berkaitan dengan wewenang bidan dalam menangani kasus kegawatdaruratan. Ketentuan tersebut memberikan perluasan area pelayanan kepada ibu semasa persalinan karena semasa persalinan ada kebutuhankebuthan pelayanan yang harus diberikan dalam rangka menjaga kesehatan ibu yang sedang dan atau setelah persalinan termasuk merawat bayi yang bertujuan untuk menolong sebelum dilakukan penanganan yang lebih intensif, sehingga ada kewenangan situasional yang diberikan kepada profesi kebidanan pada tempat-tempat tertentu yang tidak/ belum ada dokter. Di tempat ini profesi bidan boleh melakukan tindakan diluar kewenangannya untuk melakukan tindakan pelayanan kesehatan diluar kewenangannya

c) Hubungan Standar Kompetensi Bidan dalam kegawatdaruratan persalinan dengan Kewenangan dalam pelayanan kegawatdaruratan persalinan

Terdapat hubungan antara kompetensi yang diberikan dengan kewenangan dalam melakukan suatu tindakan kegawatdaruratan. Penguasaan kompetensi profesi bidan hanya dapat diimplementasikan dalam asuhan kebidanan ketika memiliki kewenangan yang dalam hal ini lisensi dari institusi Dinas kesehatan setempat, demikian juga lisensi penyelenggaraan asuhan akan diberikan bila profesi memiliki kompetensi yang dibuktikan dengan kepemilikan ijazah dan sertifikasi kompetensi.

\section{SARAN}

a) Agar pemerintah melalui Dinas Kesehatan setempat menegaskan ketentuan standar kompetensi bidan yang disesuaikan dengan kualifikasi pendidikan profesi bidan dan cakupan kewenangan sehingga menimbulkan keraguan bagi profesi bidan dan mendapat kepastian kewenangan yang sesuai ketentuan hokum yang mengaturnya yang pada akhirnya pelayanan asuhan kebidanan dapat diberikan secara optimal.

b) Agar bidan tetap harus melaksanakan pelayanan persalinan secara profesional sesuai dengan standar kompetensi yang berlaku, sehingga tetap mendapatkan perlindungan dan kepastian hukum dalam melaksanakan praktik kebidanan baik di tempat praktik perseorangan maupun di institusi pelayanan kesehatan. 
SOEPRA Jurnal Hukum Kesehatan

TERAKREDITASI RISTEKDIKTI Peringkat 4

ISSN:2548-818X (media online) Vol. 7 (1) Juni 2021

c) Agar masyarakat mendapatkan kepastian tentang standar kompetensi profesi bidan serta cakupan kewenangan dalam melakukan tindakan asuhan kebidanan, sehingga masyarakat pengguna jasa pelayanan kebidanan memperoleh pelayanan yang efektif, efisien dan akuntable.

\section{DAFTAR PUSTAKA}

A. Sonny Keraf \& Mikhael Dua, 2001, Ilmu Pengetahuan (Sebuah Tinjauan Filosofis), Yogyakarta: Kanisius

Daryl Koehn. 2000. Landasan Etika Profesi. Yogyakarta. Kanisius.

Juniarso R dan Achmad S, , 2009. Hukum Administrasi Negara dan Kebijakan Publik, Bandung. Nuansa

Kanter. 2001. Etika Profesi Hukum : Sebuah Pendekatan Sosio-Religius. Jakarta. Storia Grafika.

Ridwan HR. 2007. Hukum Administrasi Negara. Yogyakarta. PT Raja Grafindo Persada

Sedarmayanti \& Syarifudin Hidayat, 2002, Metodologi Penelitian, Bandung : Mandar Maju 